Dept. of Animal and Poultry Production,

Faculty of Agriculture, Assiut University, Assiut, Egypt

\title{
THE EFFECT OF DIETARY CRUDE FIBER ON DANDARAWI LAYING HENS PERFORMANCE, BLOOD SERUM, AND YOLK CHOLESTEROL CONCENTRATIONS
}

(With 4 Tables)

By

\section{H.A. MAHMOUD}

(Received at 13/3/2008)

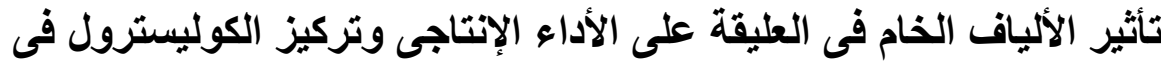

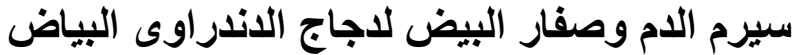

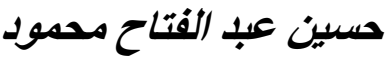

أجريت هذه التجربة لدر اسة تأثثر زيادة مستوى الأيساف الخـام فى العليقة على الأداء الإنتاجى

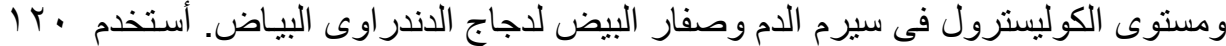

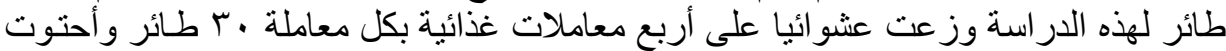

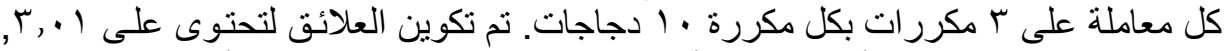

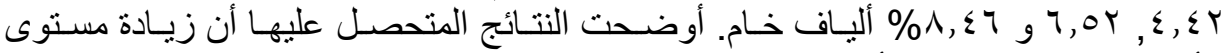

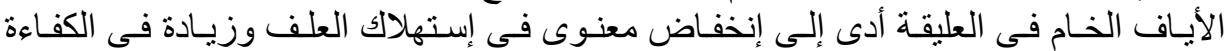

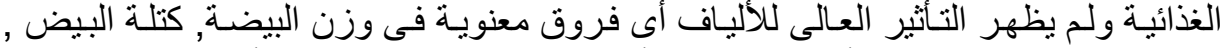

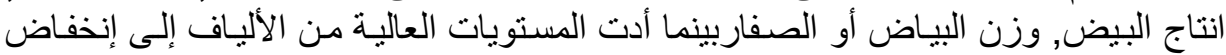

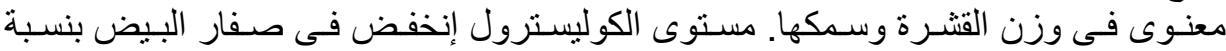

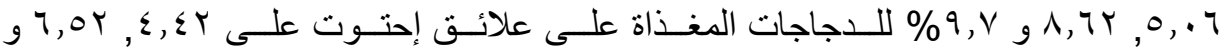

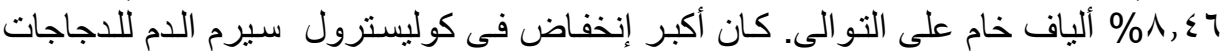

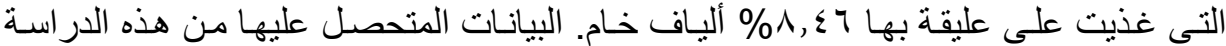

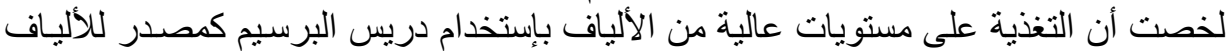

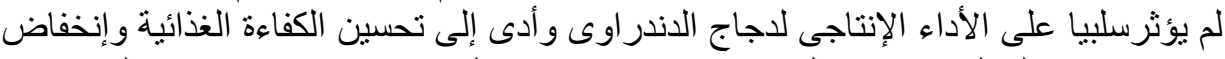

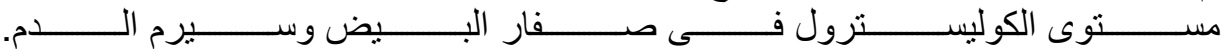

\section{SUMMARY}

A trial was performed to study the effect of increasing dietary crude fiber level on the performance, blood serum and yolk cholesterol concentrations of Dandarawi laying hens. A total of one hundred twenty, 32 weeks old Dandarawi laying hens were randomly assigned to four dietary treatments of 30 hens each (three replicate of 10 hens each). Diets were formulated to have $3.01,4.42,6.52$, and $8.46 \%$ crude fiber (CF). The experiment prolonged for 3 months results indicated that increasing dietary CF significantly increased feed efficiency while feed 
consumption was decreased. Dietary CF levels had no significant effect on weight gain; egg mass, egg production, albumen and yolk weight. Shell weight, percent and thickness were significantly decreased as dietary CF increased. Milligrams yolk cholesterol per $\mathrm{g}$ of yolk decreased as hens were fed increasing dietary CF levels. Total cholesterol per yolk decreased by 5.06, 8.62 and $9.7 \%$ at feeding CF levels of 4.42, 6.52 and $8.46 \%$, respectively; as compared to the control diet (3.01CF). Serum cholesterol was significantly decreased when the dietary CF was increased; the lowest reduction (29\%) of cholesterol in serum was found in hens fed diet contained $8.46 \% \mathrm{CF}$. In conclusion, data reported in this study indicated that yolk and serum cholesterol was reduced by increasing levels of CF. Furthermore, feeding clover hay as fiber source in diet of Dandarawi laying hens reduced yolk cholesterol without adversely affecting either egg production or egg mass furthermore, feed efficiency was significantly improved.

Key words: Crude fiber, laying hens, cholesterol, performance, Egg quality, Egg production.

\section{INTRODUCTION}

From the consumer's point of view, fat is associated with poor dietetic quality and moreover, consumer awareness of correlation between saturated fat consumption and obesity or coronary heart disease has stimulated the demand for low fat products of animal origins. Laying hens generally are not fed products of animal origin and usually meet their bodies' needs for cholesterol entirely by de novo synthesis. In addition, most of the cholesterol in laying hen plasma resides in the very low-density lipoprotein (VLDV) fraction (Elkin et al., 1999). As stated by Holden et al., (1989), the average cholesterol content of one large egg is $208 \mathrm{mg}$. Kritchevsky and Kritchevsky (2000) recommended that people should limit the consumption of eggs because of their high cholesterol content. Hence, the cholesterol scare may have created a severe negative influence on consumer's attitude toward eggs. Diets containing high levels of fiber were associated with higher water content in the gastrointestinal tract and it is proposed that this improved welfare (Hocking et al., 2004). Bile acid excretion is the main eliminatory pathway of endogenous cholesterol. Increased bile acid excretion causes a decrease in the cholesterol pool and in blood cholesterol. Eastwood and Boyd (1967) observed in rats that bile salts appear to be bounded to fiber in the small intestine and therefore unavailable for bile salt reabsorption and enterohepatic recirculation. Increasing dietary fiber has been shown to significantly decrease serum cholesterol and/or artery 
deposition of plaque in humans (Trowell, 1972), rabbits (Kritchevsky et al., 1954), rat (Tsai, 1976), chicks (Fahrenbach et al., 1966 and Fisher and Griminger, 1967), turkeys (Simpson and Harms, 1969), and laying hens (Menge et al., 1974 and Hussein et al., (1976). Truk and Barnett (1972) found that alfalfa, when added to corn-soy laying hen diet, was most effective of the fiber sources tested for decreasing egg cholesterol with the least loss of egg size, feed efficiency, and egg production, while cellulose only slightly reduced egg cholesterol. Therefore, this experiment was conducted to determine the effect of fiber sources and level on yolk and serum cholesterol and performance of Dandarawi laying hens using natural fiber sources that might be added to practical laying hen diets.

\section{MATERIALS and METHODS}

This experiment was carried out at the Poultry Farm, Animal and Poultry Production Department, Faculty of Agriculture, Assiut University. One hundred twenty Dandarawi laying hens were 32 weeks old were divided into four groups of 30 birds each and housed individually in wire cages. A row of 10 cages was considered as one block per treatment. They were fed diets consisting of various levels of fiber $(3.01,4.42,6.52$, and $8.46 \mathrm{CF} \%$ ) ad libitum over a 3 month experimental period. All dietary treatments were isonitrogenous and isoenergetic. All birds subjected to photoperiod of 16 hours light and $8 \mathrm{~h}$ dark daily. Feed samples were taken and analyzed according to AOAC methods (1990). The composition of experimental diets used is shown in Table (1).

Egg production, fed consumption, feed efficiency, egg weight, egg quality and survivability were determined periodically throughout the experiment. At the end of $2^{\text {nd }}$ and $3^{\text {rd }}$ month of the experiment blood samples were collected from six randomly selected hens from each treatment. Serum was separated by centrifugation for 10 minutes (300 rpm) and stored in vials at $-20^{\circ} \mathrm{C}$ for later analyses. Frozen serum was thawed and assayed for cholesterol values by enzymatic colorimetric test (CHOD-PAP) using commercial kits purchased from Bioub (Germany). Yolk cholesterol was determined in eggs laid in the last three days the of second and third month of the experiment. Collected eggs were broken and yolk separated and weighed, then pooled and frozen at $-18{ }^{\circ} \mathrm{C}$ until analyzed in duplicate samples. Yolk cholesterol was extracted according to the method of Folich et al., (1956) as modified by Washburn and Nix 91974) and estimated by the method of Zlatkis et al. (1953) using a cholesterol diagnostic kit. 
Analysis of variance (ANOVA) was performed on the yield data using the general linear model (GLM) of Statistical Analysis System (SAS, 1992). The analysis was carried out according to the following model:

$$
\mathbf{Y}_{\mathbf{i j}}=\boldsymbol{\mu}+\mathbf{L}_{\mathbf{i}}++\mathbf{E}_{\mathbf{i j}}
$$

Where $Y_{i j}$ is the observation of the CF levels, $\mu$ is the overall mean, $\mathrm{L}_{\mathrm{i}}$ is the effect of CF level, and $\mathrm{E}_{\mathrm{ij}}$ is the random error. When a significant effect $(\mathrm{P}<0.05)$ was proved, differences between treatment means were tested for significant by least squares means (LSM) or Duncan's test as explained by Steel and Torrie (1960).

\section{REULTS}

Table 1: Composition of the experimental diets

\begin{tabular}{|l|c|c|c|c|}
\hline Ingredient & $\begin{array}{c}\text { Diet1 } \\
\text { (Control) }\end{array}$ & Diet 2 & Diet 3 & Diet 4 \\
\hline Ground yellow corn(8.5\% CP & 58.21 & 51.94 & 40.60 & 29.87 \\
\hline Soybean meal(44\% CP) & 27.70 & 25.80 & 24.46 & 23.00 \\
\hline Clover hay meal & 00 & 6.22 & 15.60 & 24.65 \\
\hline Mixed oil & 3.05 & 5.00 & 8.30 & 11.44 \\
\hline Dicalcium phosphate & 1.74 & 1.74 & 1.74 & 1.74 \\
\hline Limestone & 8.50 & 8.50 & 8.50 & 8.50 \\
\hline Salt & 0.35 & 0.35 & 0.35 & 0.35 \\
\hline Premix* & 0.23 & 0.23 & 0.23 & 0.23 \\
\hline DL-Methionine(99\%) & 0.22 & 0.22 & 0.22 & 0.22 \\
\hline Total & 100 & 100 & 100 & 100 \\
\hline & & & & \\
\hline Calculated analysis & & & & \\
\hline ME, Kcal/Kg & 2842 & 2840 & 2840 & 2840 \\
\hline CP\% & 17.10 & 17.03 & 16.94 & 16.90 \\
\hline Crude fiber & 3.01 & 4.42 & 6.52 & 8.46 \\
\hline Ether Extract & 5.44 & 7.30 & 10.35 & 13.25 \\
\hline Calcium \% & 3.54 & 3.52 & 3.50 & 3.50 \\
\hline Available phosphorus \% & 0.52 & 0.52 & 0.52 & 0.52 \\
\hline
\end{tabular}

Each package of $1 \mathrm{~kg}$ contain: 2million IU vit. A; 1.5 million IU vit. D; $330 \mathrm{mg}$ vit. K; $830 \mathrm{mg}$ vit. E;20000 mg CholineChloride; $830 \mathrm{mg}$ Nicotinc Acid; $35 \mathrm{mg}$ vit. B6; $330 \mathrm{mg}$ vit. B1; $1000 \mathrm{mg}$ vit. B2; $1.75 \mathrm{mg}$ vit. B12; $35 \mathrm{mg}$ Biotin; $85 \mathrm{mg}$ Folic Acid; $335 \mathrm{mg}$ Panyotheinic Acid6670 mg Mg; $500 \mathrm{mg} \mathrm{Cu} ; 35 \mathrm{mg} \mathrm{I} ; 17 \mathrm{mg} \mathrm{Se} ; 12500 \mathrm{mg}$ Fe5000 mg Mn; $11660 \mathrm{mg} \mathrm{Zn} ; 17 \mathrm{mg}$ Cobalt.

Table 2: Effect of Different Levels of Crude Fiber on Blood Serum and Egg Yolk Cholesterol Levels.

\begin{tabular}{|c|c|c|}
\hline \multirow[t]{2}{*}{ Dietary treatments } & \multicolumn{2}{|c|}{ Cholesterol values } \\
\hline & Serum $(\mathrm{mg} / 100 \mathrm{ml})$ & Yolk (mg/g) \\
\hline $3.01 \% \mathrm{CF}$ & $137.36 \pm 12.2^{\mathrm{a}}$ & $12.06 \pm 0.2^{\mathrm{a}}$ \\
\hline $4.42 \% \mathrm{CF}$ & $118.58 \pm 13.1^{\mathrm{ab}}$ & $11.45 \pm 0.0^{\mathrm{a}}$ \\
\hline $6.52 \% \mathrm{CF}$ & $106.41 \pm 10.42^{\mathrm{a}}$ & $11.02 \pm 0.1^{\mathrm{b}}$ \\
\hline $8.46 \% \mathrm{CF}$ & $97.37 \pm 11.7^{\mathrm{cb}}$ & $10.89 \pm 0.4^{\mathrm{b}}$ \\
\hline Significance & $*$ & $*$ \\
\hline
\end{tabular}


Assiut Vet. Med. J. Vol. 54 No. 117 April 2008 


\section{DISUCSSION}

Laying hen's performance: Table (3) summarized the effects of dietary crude fiber on body weight, egg number, egg production, egg mass, feed intake, feed efficiency and survivability. Body weight gain of hens was not significantly $(\mathrm{P}<0.05)$ affected by increasing dietary crude fiber. This result is in agreement with that of Hammad, (2005), Abdel-Azeem (2005) and Vargas and Naber (1984). Feed intake of birds fed dietary fiber at levels of 5 and $7 \%$ was significantly decreased when compared to the control group. Similar findings were reported by Abdel-Azeem (2005); Chaturvedi and Singh (2000); Wess and Scot (1978) and James (1978). However, feed efficiency was significantly increased as CF was increased. Compared with other dietary groups, fed high dietary $\mathrm{CF}$ the level of $8.46 \%$ crude fiber showed a little improvement in feed efficiency. These results agreed with those of Adeyemi and Familade (2003) and Hetland (2003) who reported that the coarse insoluble fiber could improve feed conversion if poultry fed highly fiber diets. Improvement of feed efficiency is thought to be due partly to increase digestibility of starch and may be due to increase of gizzard activity.

Insignificant decrease was showed in egg mass and egg number per hen when the hens received high fiber diets. These results are in agreement with those obtained by Roth-Maier and Krichgessner (1998), they concluded that maize-cob-mix with up to $7 \%$ crude fiber can be used successfully as energy source for laying hens. No significant differences were observed in egg production due to crude fiber levels. The obtained results are in agreement with the findings of Vargas and Naber (1984); Hennig et al., (1990); Piliang (1990), and Hammad (2005). According to survivability, no significance effects were detected among dietary fiber.

Egg quality traits: The results of egg quality measurements as affected by dietary fiber levels are presented in Table (4). No significant differences in albumen, yolk weight, and yolk index were fond due to diets fiber contents variation. Results reported herein are in harmony with those obtained by Abdel-Azeem (2005) and Hammad (2005). However, shell weight and shell thickness significantly decreased as dietary fiber increased in the diet of laying hens. This result was disagreed with those of Roberts (2004); Adeyemi and Familade (2003) and Abdel-Azeem (2005) who found that dietary crude fiber did not influence shell thickness. 
In conclusion, the data reported herein indicated that the dietary crude fiber led to a significant increase in feed efficiency, while feed intake and shell thickness were decreased. Dietary crude fiber had no significant effects on weight gain, egg mass, egg production, yolk, albumen weight and yolk index.

Serum and egg yolk cholesterol: The effect of various level of fiber upon serum and egg cholesterol values is shown in Table (2). Egg weight were separated into two distinct egg weight $40 \pm 2 \mathrm{~g}$ or $45 \pm 2 \mathrm{~g}$ and egg yolk cholesterol was determined in each group. Eggs of similar weights were taken in order to delete any possible interaction of egg weight and yolk cholesterol. Milligrams yolk cholesterol per $\mathrm{g}$ of yolk decreased as hens were fed increasing dietary fiber levels. Total cholesterol per yolk decreased by 5.06, 8.62 and $9.7 \%$ at feeding dietary crude fiber levels of $4.42,6.52$ and $8.46 \%$ respectively; as compared to the control diet. Also, serum cholesterol was significantly decreased when the dietary CF was increased, the lowest reduction (29\%) in serum was found in hens fed diet contained $8.46 \%$ CF. Although dietary fat increased as dietary fiber increased (Table 1), the conclusion reached was that only dietary fiber influenced yolk cholesterol. Miller and Katsoulis (1974) found no significant differences in ether blood serum or egg yolk cholesterol concentration with increasing dietary animal fat. The results obtained from this study are in agreement with those by Weiss and Scott (1979) who reported that the alfalfa meal produced a significant lowering in plasma cholesterol in the hens. Hargis (1988) reported that fiber influences cholesterol, binding with the bile salts in the intestinal tract, shortening intestinal transit time and increasing fecal sterol excretion. Alfalfa meal, when added to corn-soy laying hen diet, was the most effective of fiber sources tested for reducing egg cholesterol with the least loss of egg size, feed efficiency, and egg production (Turk and Barnett, 1972). The results obtained from Story Krtichevsky (1976) indicated that cellulose bound an average of $1.4 \%$ of all the bile acids tested, whereas alfalfa bounded $15.9 \%$; thus alfalfa was most successful in reducing bile acid. Data reported in this study indicated that yolk cholesterol was reduced with increasing levels of dietary fiber. Furthermore, feeding alfalfa as fiber source in the diet of Dandarawi laying hens reduced yolk cholesterol without adversely affecting either egg production or egg mass. 


\section{REFERENCES}

Abdel-Azeem, F.A. (2005): Studies on the effect of different crude fiber levels on laying Japanese quail (Conturnix Coturnix Japonica) Egypt Poult. Sci. 25: 11, 241-257.

Adeyemi O.A. and Familade, F.O. (2003): Replacement of maize by rumen filtrate fermented corn-cob in layer diets. Bioresource Technology, 90: 2, 221-224 (cited from Hammad, 2005).

Association of Analytical Chemists, (1990): Official Method of Analysis $15^{\text {th }}$ ed. Association of Anlytical Chemists, Washington, DC

Chaturvedi, V.B. and Singh, K.S. (2000): Intake and digestibility of nutrients in chicken fed diets based on rice, Indian J. of Poultry Sci. 35, 3, 318-321.

Duncan, D.B. (1955): Multiple range and multiple F test Biometrics 11: $1-42$.

Eastwood, M.A. and Boyd, G.S. (1967): The distribution of bile salts along the small intestine of rate. Biochim. Biophys. Acta 137, 393-396.

Elkin, R.G.; Zhihong, Y.; Yuan, Z.; Donkin, S.; Buhman, K.K.; Story, J.A.; Turek, J.J.; Porter, R.E.; Anderson, M.; Haman, R. and Newton, R.S. (1999): Select 3-hydroxy-3-methylglutarylcoenzyme A reductase inhibitors vary in their ability to reduce egg yolk cholesterol levels in laying hens through alteration of hepatic cholesterol loiosynthesis and plasma VLDL. J. Nutr., 129: 1010-1019.

Fahrenbach, M.J.; Riccardi, B.A. and Grant, W.C. (1966): Hypocholesterlemic activity of mucilaginous polysaccharides in White Leghorn cockerels. Proc. Soc. Exp. Biol. Med. 123, 321-326.

Feed Formulation System (1995): The Brill Corporation (version 7) 2250 Northwinde, Parkway. Suite 225. Alpharetta, GA 30004, USA.

Fisher, H. and Grminger, P. (1967): Cholesterol- lowering effects of certain grains and of oat fractions in the chick. Proc. Soc. Exp. Biol. Med. 126, 108-111.

Folich, J.; Less, M. and Salone-Stanley, G.H. (1956): A simple method for the isolation and purification of total lipids from animal tissues. J. Biol. Chem. 226: 497-509 
Hammad, A.M.S. (2005): Effect of dietary crude fiber levels on layers performance 2- rice husks as a source of fiber. Egypt. Pout. Sci. 25, 1017-1030.

Hargis, P.S. (1988): Modifying egg yolk cholesterol in the domestic fowl-a review. World's Poultry Sci. J. 44: 17-29.

Hennig, A.; Richter, G.; Grum, M. and Zander, R. (1990): The influence of a very high straw supply as fiber source on the mineral status of the broiler hen. Nohrung, 34: 2, 189-193 (cited from Hammad, 2005).

Hetland, H. (2003): Role of structural components on gut function and feed utilization in poultry. Ph.D thesis, Universitestet fo miljoog biovitenskab (UMB) IHA. Postboks 5003, 1423 As. CAB Abstracts 2003/11-2004/7, Record 1281 of 1390 (cited from Hammad, 2005).

Hocking, P.M.; Zaczek, V.; Jones, E.K.M. and Mascleod, M.G. (2004): Different concentration and sources of dietary fiber may improve the welfare of female broiler breeders. Brit. Poul. Sci. 45 (1): 9-19.

Holden, J.; Exler, J.; McCharen C. and Lokard, J. (1989): A nationwide study of cholesterol, proximate, vitamin and mineral levels in larg eggs. Fed Am. Soc. Expt. Bio., 3: A658.

Hussein, M.D.; Krueger, W.F.; Fanguy, R.C. and Bradley, J.W. (1976): Blood serum and egg yolk cholesterol in hens as influence by wheat middling and oats in the diet. Poul. Sci 55, 1595.

James, L. McNaughton (1978): Effect of dietary fiber on egg yolk, liver, and plasma cholesterol concentration of laying hen J. Nutr. 108: 1842-1848.

Kritchevsky, D.; Moyer, A.W.; Tesar, W.C.; Logan, J.B.; Brown, R.A.; Davies, M.C. and Cox, H.R. (1954): Effect of cholesterol which in experimental atherosclerosis. Am. J. Physio. 178: 3032

Kritchevsky, S.B. and Kritchevsky, D. (2000): Egg consumption and cornery heart disease an epidemiologic overview. J. Amm. Coll. Nutr., 19: 549-555.

Menge, H.; Littlefield L.H.; Frobish, L.T. and Weinland, B.T. (1974): Effect of cellulose and cholesterol on blood and yolk lipids and reproductive efficiency of the hen. J. Nutr. 104, 15541556.

Miller, R.I. and Katsoulis (1974): Influence of high fat diet on caged layers. Poul. Sci. 53, 1955. 
Piliang, W.G. (1990): High fiber diet and its effect on calcium and cholesterol status in laying hens. Indonsesian J. of Tropical Agriculture, I (2): 93-97 (cited from Hammad, 2005).

Roberts, J.R. (2004): Factor affecting egg internal quality and egg shell quality in laying hens, J. Poul. Sci., 41 (3): 161-177.

Roth-Maier, D.A. and Krichgessner, M. (1988): Corn-cob mix in poultry feeding. Ubersichten-zur-Tierernahrung, 16 (2): 213-222 (cited from Hammad, 2005).

SAS Institute (1992): SAS User's Guide: Statistcs. Version 6, SAS Institute., Cary, NC.

Simpson, C.F. and Harms, R.H. (1969): Influence of oat fractions on diethlstilbesteroi-induced aortic ruptures of turkey. Poul. Sci. 48, 1757-1761

Steel, R.G.D. and Torrie, J.H. (1960): Principles and procedures of statistics Mc Graw-Hill Book Co., Inc., New York, Ny.

Story, J.A. (1976): Influence of fiber on cholesterol and bile acid metabolism. The role of fiber in the diet, $10^{\text {th }}$ Ann. Symp. 1975, Special Rep. No. 21, NYS Ag. Exp. Sta., Geneva.

Trowell, H. (1972): Ischemic heart disease and dietary fiber. Am. J. Clin. Nutr. 25, 926-932.

Tsai, A.C.; Elisa, J.; Kelly, J.J.; Lin, R.S.C. and Robson J.R.K. (1976): Influence of certain dietary fibers on serum and tissue cholesterol levels in hen J. Nutr. 106: 188-123

Turk, D.E. and Barnett, B.D. (1972): Diet and egg cholesterol content. Poul. Sci. 51, 1881.

Vargas, R.E. and Naber, E.C. (1984): Relationship between dietary fiber and nutrient density and its effect on energy balance, egg yolk cholesterol and hen performance. J. Nutr. 114(4): 645-652.

Weiss, F.G. and Scott, L. (1979): Effect of dietary fiber, fat and total energy upon plasma cholesterol and other parameters in chickens J. Nutr. 109: 693-701.

Zlatkis, A.; Zak, B. and Boyle, A.J. (1953): A new method for the direct determination of serum cholesterol. J. Lab. Clin. Med 41: 486487. 
Assiut Vet. Med. J. Vol. 54 No. 117 April 2008 
Table 3: Effect of dietary crude fiber on Dandarawi laying hens performance

\begin{tabular}{|c|c|c|c|c|c|c|c|c|c|c|}
\hline $\begin{array}{l}\text { Dietary } \\
\text { treatment }\end{array}$ & $\begin{array}{l}\text { Initial body } \\
\text { weight }(\mathrm{g})\end{array}$ & $\begin{array}{l}\text { Final body } \\
\text { weight }(\mathrm{g})\end{array}$ & $\begin{array}{l}\text { Body weight } \\
\text { gain }(\mathrm{g})\end{array}$ & $\begin{array}{c}\text { Feed intake } \\
\text { (g/day) }\end{array}$ & $\begin{array}{l}\text { Egg weight } \\
\text { (g) }\end{array}$ & $\begin{array}{l}\text { Egg number } \\
\text { / } 30 \text { day }\end{array}$ & $\begin{array}{l}\text { Egg mass } \\
\text { (g/ 30day) }\end{array}$ & $\begin{array}{c}\text { Egg } \\
\text { production } \\
(\%)\end{array}$ & $\begin{array}{c}\text { Feed } \\
\text { efficiency (g } \\
\text { egg/g feed) }\end{array}$ & $\begin{array}{c}\text { Survivability } \\
(\%)\end{array}$ \\
\hline $3.01 \% \mathrm{CF}$ & $1507 \pm 54$ & $1901 \pm 46^{\mathrm{a}}$ & $394 \pm 42^{b}$ & $124.2 \pm 1.4^{\mathrm{a}}$ & $46.86 \pm 0.19$ & $17.3 \pm 0.7$ & $810.68 \pm 28$ & $57.67 \pm 1.7$ & $0.22 \pm 0.01^{\mathrm{a}}$ & 100 \\
\hline $4.42 \% \mathrm{CF}$ & $1522 \pm 49$ & $1924 \pm 56$ & $402 \pm 54^{\mathrm{b}}$ & $92.6 \pm 1.8^{\mathrm{b}}$ & $44.32 \pm 0.21$ & $16.9 \pm 0.4$ & $749.00 \pm 37$ & $56.33 \pm 2.4$ & $0.27 \pm 0.01^{\mathrm{b}}$ & 100 \\
\hline $6.52 \% \mathrm{CF}$ & $1486 \pm 52$ & $1851 \pm 53$ & $365 \pm 26^{a}$ & $85.3 \pm 1.9^{b}$ & $42.97 \pm 0.36$ & $16.5 \pm 0.6$ & $709.00 \pm 25$ & $55.00 \pm 1.9$ & $0.28 \pm 0.03^{\mathrm{b}}$ & 100 \\
\hline $8.46 \% \mathrm{CF}$ & $1502 \pm 50$ & $1863 \pm 45$ & $361 \pm 40$ & $75.2 \pm 2.0^{c}$ & $41.13 \pm 0.45$ & $16.1 \pm 0.8$ & $662.19 \pm 23$ & $53.67 \pm 2.6$ & $0.29 \pm 0.01^{\mathrm{b}}$ & 100 \\
\hline Significance & NS & NS & NS & * & NS & NS & NS & NS & * & NS \\
\hline
\end{tabular}

${ }^{\mathrm{ab}}$ means within a column within the same character, with different superscripts are significantly $\operatorname{different}(\mathrm{P}<0.05)$

Statistical significant by analysis of variance, NS = not significant

Table 4: Effect of dietary crude fiber on egg quality traits of Dandarawi laying hens performance

\begin{tabular}{|c|c|c|c|c|c|c|c|c|c|}
\hline $\begin{array}{c}\text { Dietary } \\
\text { treatment }\end{array}$ & $\begin{array}{c}\text { Egg weight } \\
(\mathrm{g})\end{array}$ & $\begin{array}{c}\text { Albumen } \\
\text { weight }(\mathrm{g})\end{array}$ & $\begin{array}{c}\text { Albumen } \\
(\%)\end{array}$ & $\begin{array}{c}\text { Yolk weight } \\
(\mathrm{g})\end{array}$ & $\begin{array}{c}\text { Yolk } \\
(\%)\end{array}$ & $\begin{array}{c}\text { Shell } \\
\text { weight } \\
(\mathrm{g})\end{array}$ & $\begin{array}{c}\text { Shell } \\
(\%)\end{array}$ & $\begin{array}{c}\text { Shell thickness } \\
\mathrm{mm}\end{array}$ & $\begin{array}{c}\text { Yolk } \\
\text { Index } \\
(\%)\end{array}$ \\
\hline $3.01 \% \mathrm{CF}$ & $46.6 \pm 2.2$ & $22.55 \pm 0.21$ & $48.39 \pm 0.82$ & $15.72 \pm 0.29$ & $33.73 \pm 0.28$ & $5.96 \pm 0.08^{\mathrm{a}}$ & $12.79 \pm 0.45^{\mathrm{a}}$ & $0.35 \pm 0.01^{\mathrm{a}}$ & $48.77 \pm 1.43$ \\
\hline $4.42 \% \mathrm{CF}$ & $44.2 \pm 2.3$ & $21.92 \pm 027$ & $49.59 \pm 0.64$ & $14.35 \pm 0.32$ & $32.47 \pm 0.39$ & $5.14 \pm 0.16^{\mathrm{a}}$ & $11.62 \pm 0.37^{\mathrm{b}}$ & $0.31 \pm 0.01^{\mathrm{b}}$ & $47.95 \pm 1.56$ \\
\hline $6.52 \% \mathrm{CF}$ & $41.3 \pm 2.7$ & $19.43 \pm 0.12$ & $47.10 \pm 0.46$ & $14.33 \pm 0.34$ & $34.74 \pm 0.36$ & $4.27 \pm 0.11^{\mathrm{b}}$ & $10.35 \pm 0.63^{\mathrm{b}}$ & $0.28 \pm 0.0^{\mathrm{b}}$ & $45.13 \pm 1.23$ \\
\hline $8.46 \% \mathrm{CF}$ & $40.2 \pm 1.2$ & $19.82 \pm 0.18$ & $49.25 \pm 0.97$ & $13.86 \pm 0.11$ & $34.44 \pm 0.63$ & $4.12 \pm 0.05^{\mathrm{b}}$ & $10.23 \pm 0.72^{\mathrm{b}}$ & $0.24 \pm 0.0^{\mathrm{c}}$ & $45.32 \pm 1.22$ \\
\hline Significance & $\mathrm{NS}$ & $\mathrm{NS}$ & $\mathrm{NS}$ & $\mathrm{NS}$ & $\mathrm{NS}$ & $*$ & $*^{*}$ & $*$ \\
\hline
\end{tabular}

${ }^{\mathrm{ab}}$ means within a column within the same character, with different superscripts are significantly $\operatorname{different}(\mathrm{P}<0.05)$

Statistical significant by analysis of variance, NS = not significant 